\title{
Efektivitas Penyerapan Dana PKH dalam Meningkatkan Kesejahteraan Masyarakat di Desa Gereneng Lombok Timur
}

\author{
Nita Piana \\ Universitas Hamzanwadi \\ nita.piana@gmail.com
}

\begin{abstract}
Abstrak
Penelitian ini bertujuan untuk menjelaskan dampak pelaksanaan $\mathrm{PKH}$ dalam meningkatkan kesejahteraan masyarakat, dan efektivitas penyerapan dana $\mathrm{PKH}$ dalam meningkatkan kesejahteraan masyarakat di Desa Gereneng Lombok Timur. Metode penelitian yang digunakan adalah metode deskriptif kualitatif. Teknik pengumpulan data menggunakan teknik observasi, wawancara, dan dokumentasi. Teknik analisis data menggunakan teknik reduksi data, penyajian data, dan penarikan kesimpulan. Hasil penelitian menunjukkan bahwa dana PKH dapat dikatakan sudah efektif walaupun belum maksimal. Setidaknya dengan adanya program ini kehidupan masyarakat bisa hidup lebih baik dari sebelumnya. Telah terlihat bahwasanya semangat orang tua untuk menyekolahkan anaknya agar bisa menjadi penerus bangsa dan kelak bisa hidup lebih sejahtera. Dalam konteks ini PKH telah berhasil menyelamatkan anak-anak yang kurang mampu dari putus sekolah.
\end{abstract}

Kata Kunci: Efektivitas, Dana PKH, Kesejahteraan, Masyarakat

\begin{abstract}
This study aims to explain the impact of $\mathrm{PKH}$ implementation in improving community welfare, and the effectiveness of PKH fund absorption in improving community welfare in Gereneng Village, East Lombok. The research method used is descriptive qualitative method. Data collection techniques using observation techniques, interviews, and documentation. The data analysis technique uses data reduction techniques, data presentation, and drawing conclusions. The results showed that PKH funds can be said to have been effective, although not yet maximized. At least with this program people's lives can live better than before. It has been seen that the spirit of parents to send their children to school so that they can become the nation's successors and later can live more prosperously. In this context, $\mathrm{PKH}$ has succeeded in saving underprivileged children from dropping out of school.
\end{abstract}

Keywords: Effectiveness, PKH Funds, Welfare, Society

\section{Pendahuluan}

Masalah ekonomi dan sosial di Indonesia yang belum teratasi dari dulu hingga saat ini yaitu tingkat pertumbuhan dan jumlah penduduk yang tinggi tetapi tidak dibarengi dengan kesempatan kerja yang memadai. Pengangguran menjadi hal yang umum terdapat di masyarakat karena mereka masih kesulitan dalam mencari kerja. Permasalahan muncul 
mengingat kebijakan yang dikeluarkan oleh pemerintah saat ini masih belum mampu untuk mengatasi masalah kemiskinan dan pengangguran yang masih banyak dialami oleh masyarakat Indonesia.

Kemiskinan merupakan masalah yang sangat mendasar bagi negara berkembang, salah satunya Lombok Timur lebih khususnya. Salah satu penyebab utama dari kemiskinan adalah pengangguran. Sempitnya lapangan pekerjaan dan rendahnya pendidikan serta keterampilan, membuat para pengangguran kemudian beralih ke mata pencaharian di sektor pertanian. Sektor pertanian sangat dominan dalam perekonomian desa, namun luas lahan yang semakin sempit tidak seimbang dengan bertambahnya jumlah penduduk setiap tahun. Akibatnya, jumlah pengangguran dan buruh tani terus meningkat tanpa bertambahnya luas tanah.

Kemiskinan merupakan masalah penting bagi semua yang ada di dunia (Asrinati, 2017: 1), khususnya di Lombok Timur. Sejak negara ini merdeka kemiskinan menjadi masalah yang serius di Lombok Timur. Masalah kemiskinan yang begitu kompleks berkaitan dengan aspek, yaitu aspek sosial, budaya, ekonomi dan aspek yang lainnya. Kemiskinan yang terjadi di dalam di Lombok Timur harus diperhatikan sebagai masalah yang serius, karena kemiskinan membuat banyak masyarakat mengalami kesulitan dalam memenuhi kebutuhan sehari-hari. Kemiskinan di Lombok Timur merupakan salah satu penyakit dalam ekonomi, sehingga harus ada solusi atau kebijakan untuk mengurangi tingkat kemiskinan. Pada tahun 2016 penduduk miskin di Lombok Timur ada sekitar 216.180 dengan prosentase sekitar 18,46\% (BPS NTB, 2018).

Ketika jumlah pengangguran di suatu negara mengalami peningkatan maka pembangunan ekonomi di negara tersebut sedang tidak sejahtera dan sebaliknya apabila jumlah pengangguran menurun maka negara tersebut sejahtera (Hardoyo, 2015). Ketika pengangguran mengalami peningkatan, maka pemerintah harus melakukan tindakan seperti, menambah lapangan usaha. Namun apabila pemerintah tidak menambah lapangan usaha yang telah ada maka pengangguran akan terus meningkat. Dalam konteks Lombok Timur, ketika pengangguran meningkat maka penduduk Lombok Timur tidak akan mendapatkan pendapatan untuk memenuhi kebutuhan sehari-hari, sehingga akan menyebabkan kemiskinan. Masyarakat Lombok Timur tidak bisa memenuhi kebutuhan hidup sehari-hari ketika mereka masih menganggur. Pengangguran terjadi karena diakibatkan oleh berbagai macam faktor. Hal ini biasanya 
dipengaruhi oleh jumlah lapangan kerja yang tersedia lebih kecil dibanding para pencari kerja, informasi tentang lowongan pekerjaan yang kurang meluas (Fauziyah, 2018). Tingkat pengangguran di Lombom Timur berdasar data tahun 2018 dari mulai SD sampai Diploma sebesar 5,254\% (BPS NTB, 2018).

Menurut data Badan Pusat Statistik Nasional, pada tahun 2016 j umlah penduduk miskin di Lombok Timur sebesar 216,180 juta atau 18,46 \% dari total penduduk Lombok Timur yang tersebar di berbagai kecamatan yang ada di NTB (BPS NTB, 2018). Walaupun berganti-ganti sosok pemimpin di Indonesia, tidak banyak hal berarti yang dapat mereka lakukan dalam mengatasi masalah kemiskinan yang terjadi saat ini.Salah satu carapemerintah untuk mengatasi kemiskinan adalah dengan memberikan bantuan kepada masyarakat yang kurang mampu/miskin, yang disebut sebagai Bantan sosial. Bantun sosial ini dalam bentuk bantuan tunai maupun bantuan material, seperti dana BOS, Jamkesmas, Raskin, Program Keluarga Harapan (PKH), dan lain-lain. PKH ini dalam bentuk uang tunai dan sembakau.

Bantuan sosial adalah merupakan transfer uang atau barang yang diberikan kepada masyarakat guna melindungi dari kemungkinan terjadinya risiko sosial dan untuk meningkatkan kesejahteraan masyarakat. Bantuan sosial dapat diberikan secara langsung kepada masyarakat atau lembaga kemasyarakatan, sifatnya tidak terus menerus dan selektif. Bantuan sosial difokuskan untuk meningkatkan derajat hidup masyarakat agar terlepas dari permasalahan rantai kemiskinan yang berkepanjangan, mendorong dan mempercepat pertumbuhan masyarakat miskin menjadi masyarakat produktif, mandiri dan sejahtera, dengan memperbaiki dan menyempurnakan kebijakan yang sudah ada.

Kondisi sosial ekonomi masyarakat yang ada di Desa Gereneng ini kebanyakan masih hidup dibawah garis kemiskinan. Ini disebabkan oleh banyak hal yaitu karena kualitas SDM yang masih sangat rendah, banyaknya anak usia sekolah yang sudah tidak lagi bersekolah/putus sekolah, kurangnya kesadaran orang tua untuk menyekolahkan anak-anak mereka, mereka cenderung memiliki anak lebih dari dua sehingga begitu banyak beban yang harus mereka tanggung, belum lagi lapangan kerja yang terbatas, serta upah minimum pekerja yang masih rendah. Rata-rata sebagian besar masyarakat bekerja sebagai petani, dan penjual kecil-kecilan, sehingga penghasilan mereka kebanyakan tidak cukup untuk memenuhi kebutuhan sehari-hari. Pada akhirnya banyak dari mereka yang terlibat hutang untuk mencukupi kebutuhan hidupnya. Ditambah lagi 
dengan akses untuk berobat ke rumah sakit yang terbilang mahal sehingga kebanyakan dari mereka tidak mampu untuk menjangkaunya. Masyarakat cenderung lari ke obatobatan tradisional dan ke puskesmas yang fasilitasnya masih kurang lengkap dan kurang memadai. Belum lagi cara hidup masyarakat yang kurang mementingkan hidup bersih, sehingga mudah sekali terserang penyakit-penyakit.

PKH telah dilaksanakan sejak tahun 2013 di Lombok Timur. Namun sampai saat ini di Lombok Timur masih terjadi kesenjangan ekonomi yang ditunjukkan dengan timpangnya pertumbuhan pengelaran baik pangan maupun nonpangan antara kelompok masyarakat pedesaan dan perkotaan. Tidak meratanya akses terhadap layanan dasar seperti kesehatan, pendidikan, air, sanitasi, dan pelayanan dasar lainnya di desa dan di kota dapat menyebabkan kesenjangan ekonomi. Akses pelayanan di desa lebih sedikit dan lebih sulit dibandingkan di kota (Weru, 2019).

Kurangnya akses terhadap pendidikan dan kesehatan tersebut juga terjadi di Desa Gereneng, Kecamatan Sakra Timur Kabupaten Lombok Timur. Kurangnya pengetahuan dan wawasan mengenai pentingnya pendidikan dan kesehatan, serta sulitnya akses terhadap pendidikan dan kesehatan tersebut menjadi alasan mengapa masyarakat desa gereneng dapat dikatakan miskin dan berhak untuk mendapatkan bantuan dari pemerintah. Alasannya lainnya adalah faktor pekerjaan yang didominasi oleh tenaga kerja disektor pertanian yang meliputi petani dan buruh petani, yaitu sebesar $76,53 \%$ dari jumlah penduduk Desa Gereneng. Dikarenakan mayoritas pekerjaan penduduk Desa Gereneng adalah petani dan buruh tani, pendapatan merekapun tidak menentu yang dapat dipengaruhi oleh kondisi iklim dan cuaca. Dengan pendapatan yang tidak menentu disertai dengan pengeluaran atau konsumsi pangan yang lebih tinggi dari pendapatan yang tidak jarang membuat mereka untuk lebih mensampingkan pendidikan, kesehatan dan kebutuhan lainnya dengan adanya bantuan PKH yang telah diimplementasikan di Desa Gereneng kurang lebih enam tahun diharapkan sedikit banyak dapat mengurangi beban rumah tangga sangat miskin yang menjadi penerima mamfaat PKH dalam mengakses pelayanan dasar pendidikan dan kesehatan.

Beberapa penelitian telah banyak dilakukan terkait bagaimana PKH berdampak pada tingkat kesejahteraan masyarakat Indoenesia. Penelitian tersebut memperkuat penelitian ini bahwa program PKH telah banyak membantu masyarakat miskin di Indonesia (Fidyatun, 2012; Wibowo, 2012; Ekardo, Firdaus, \& Elfemi, 2014; Ma'arif, 
2018; Husni, 2018)). Keberbedaan penelitian di atas dengan penelitian ini pada efektifitas program PKH dalam meningkatkan taraf hidup masyarakat terutama di wilayah Lombok Timur Nusa Tenggara Barat. Oleh karena itu urgensi penelitian ini dipandang sangat bermanfaat untuk menjadi evaluasi bagi peningkatan program PKH agar lebih baik lagi. Adapun tujuan yang ingin dicapai oleh peneliti dalam penelitian adalah untuk mengetahu dampak pelaksanaan PKH dalam meningkatkan kesejahteraan masyarakat, dan mengetahui efektivitas penyerapan dana $\mathrm{PKH}$ dalam meningkatkan kesejahteraan masyarakat di Desa Gereneng Lombok Timur.

\section{Metode Penelitian}

Penelitian ini merupakan penelitian deskriptif kulitatif. Pada peneltian kualitatif data yang dikumpulkan berbentuk kata-kata, gambar-gambar dan kebanyakan bukan angka kalapun ada angka-angka hanya sebagai penunjang (Arikanto, 2013). Data yang dimaksud meliputi transkrip wawancara, catatan data lapangan, foto, dukumen pribadi (Sugiyono, 2017). Dalam penelitian ini peneliti menggunakan teknik pengumpulan data melalui observasi. Dalam hal ini peneliti mengadakan pengamatan langsung di tempat penelitian guna mendapat gambaran yang jelas dan nyata tentang masyarakat yang mendapatkan dana PKH bagi kesejahteraan masyarakat di Desa Gereneng. Wawancara dilakukan dengan berpedoman pada pedoman wawancara yang disiapakan sebelumnya sehingga proses wawancara diharapakan lebih terarah dan memperoleh keterangan tentang masyarakat yang mendapatkan dana PKH bagi kesejahteraan masyarakat di Desa Gereneng. Wawancara ini dituju kepada masyarakat yang mendapatkan dana PKH di Desa Gereneng. Dokumentasi dilakukan untuk mengetahui gambaran kehidupan masyarakat Gereneng dengan cara mencari biografi dan foto yang mendapatkan dana PKH terhadap kesejateraan masyarakat Gereneng. Analisis data dalam penelitian kulitatif, dilakukan pada saat pengumpulan data berlangsung, dan setalah selesai pengumpulan data dalam periode tertentu (Sugiyono, 2017). Pengolahan data dalam penelitian ini lakukan dengan tiga tahapan yaitu, reduksi data, penyajian data, dan penarikan kesimpulan dan verifikasi. Kesimpulan awal yang dikemukakan masih bersipat sementara, akan berubah bila tidak ditemukan bukti-bukti yang kuat mendukung pada tahap pengumpulan data berikutnya. Tetapi apabila kesimpulan yang dikemukaan pada tahap awal, didukung oleh bukti- bukti yang valid dan konsisten saat peneliti 
kembali ke lapangan mengumpulkan data, maka kesimpulan yang dikemukakan merupakan kesimpulan yang kredibel.

\section{Pembahasan}

\section{Kondisi Umum Desa Gereneng}

Desa Gereneng adalah salah satu Desa di Kecamatan Sakra Timur Kabupaten Lombok TimurPropinsi Nusa Tenggara Barat.Desa Gereneng terdiri dari 6 dusun dengan jumlah penduduk 6.816 jiwa,luas wilayahnya 592,100 Ha dengan permukaan tanah dataran tinggi. Jumlah penduduk Desa Gereneng Kecamatan Sakra Timur Kabupaten Lombok Timur pada tahun 2019 adalah 6.816 jiwa (Profil Desa Gereneng, 2018). Dari jumlah tersebut berjenis kelamin laki-laki 3.241 dan 3.575 berjenis kelamin perempuan. Berdasarkan data monografi antara jenis laki-laki dan jenis perempuan adalah lebih banyak jenis kelamin perempuan. Sarana pendidikan di desa Gereneng relatif memadai, hampir semua sarana pendidikan ada dari mulai TK, SD, SLTP, SLTA. Dari data di atas dapat diketahui bahwa tingkat kesadaran masyarakat desa Gereneng akan pendidikan sudah baik. Hal terbukti dengan tersedianya sarana pendidikan yang memadai.

Mata pencaharian penduduk desa Gereneng secara keseluruhan beragam, tetapi prosentase tersebut adalah sebagai buruh tani.Usia produkitf penduduk Desa Gereneng sebagian besar bekerja sebagai petani, buruh pabrik, PNS dan lain-lain. Mata pencaharian penduduk Desa Gereneng secara keseluruhan beragam, tetapi prosentase tersebut adalah sebagai petani. Usia produkitf penduduk Desa Gereneng sebagian besar bekerja sebagai petani, buruh pabrik, PNS dan lain-lain.

\section{Dampak PKH Bagi Kesejahteraan Masyarakat di Desa Gereneng Lombok Timur}

Dalam penelitian ini, peneliti melakukan wawancara dengan informan, petugas PKH dan beberapa perangkat desa Gereneng. Wawancara yang dilakukan untuk memperoleh informasi dengan bermacam responden, yang diwawancarai itu peserta PKH dan petugas PKH. Wawancara juga dilakukan dengan perangkat desa. Harapan besar bagi mereka untuk mendapatkan kehidupan yang lebih baik.Rata-rata sebagian besar masyarakat bekerja sebagai petani, dan penjual kecil-kecilan, sehingga penghasilan 
mereka kebanyakan tidak cukup untuk memenuhi kebutuhan sehari-hari.Pada akhirnya banyak dari mereka yang terlibat hutang untuk mencukupi kebutuhan hidupnya.

PKH adalah program pemberian bantuan tunai bersyarat kepada Keluarga Penerima Manfaat (KPM) yang memenuhi syarat kepersertaan dan ditetapkan oleh kementrian sosial. Menurut ibu Rapiah, sebagai peserta PKH menyatakan bahwa dengan dana PKH itu saya menambah modal usaha, karena dalam 1 tahun kita dapat 3 kali uang tunai sedangkan beras dan telur mendapatkan 1 kali sebulan dengan jumlah beras $10 \mathrm{~kg}$ dan telur 5 butir, dari pada cuma dihabisin membeli barang yang tidak berguna lebih baik di gunakan sebagai modal usaha. Dan di seluruh keluarga saya bisa baca tulisan tidak ada yang buta hurup walaupun hanya lulusan SD saja (Wawancara, 2019).

Ungkapan lain dari ibu Susi yakni, setelah saya mendapatkan dana PKH kebutuhan bisa terpenuhi, kalau di andalkan hasil dari suami jadi buruh harian saja itu tidak akan cukup untuk sehari-harinya sedangkan di keluarga ada 2 anak yang harus di penuhi kebutuhannya, belum lagi kalau salah satu dari anak ada yang sakit dan harus di periksa ke Polindes perlu biaya (Wawancara, 2019). Hal senada juga diungkapkan oleh ibu Rohani bahwa saya dan keluarga bersyukur mendapatkan dana PKH, dengan uang itu kita bisa memenuhi kebutuhan sehari-hari. Apa lagi saya seorang janda yang menghidupi 2 orang anak dengan mengandalkan hasil buruh harian saja yang di upah hanya Rp. 50.000 per hari. Sedangkan anak yang pertama baru kelas 2 SMP, setiap hari uang jajan Rp 5.000 dan anak yang kedua baru kelas 5 SD dengan uang jajan Rp 3.000. Tetapi setelah ada dana PKH ini bisa meringankan beban keluarga (Wawancara, 2019).

Menurut ibu Rohimin sebagai peserta PKH menyatakan bahwa terkadang saya heran dengan suami saya selama mendapatkan dana PKH dia malas bekerja, dia hanya mengandalkan uang PKH yang hanya cair 3 kali dalam 1 tahun. Kalau ada tetangga suruh suami kerja di sawah tetangga kadang tidak mau, hanya tidur makan saja kerjaannya. Jadi, ketika belum cair uang PKH terpaksa saya pinjam di tetangga, setelah cair dana PKH baru saya bayar hutang. Sedangkan hasil saya dari harian hanya cukup untuk kebutuhan sehari-hari (Wawancara, 2019).

Menurut ibu Sahmah sebagai peserta PKH menyatakan bahwa alhamdulillah dengan dana PKH ini saya dan anak bisa memenuhi kebutuhan sehari-hari, apalagi setiap 1 bulan di kasih juga beras $10 \mathrm{~kg}$ dan telur 5 butir. Setelah suami meninggal sayalah yang menjadi tulang punggumg keluarga dengan bertani. Di keluarga cuma saya yang tidak 
bisa baca tulisan karena dulu saya tidak pernah sekolah, dari itu saya bersemangat sekali menyekolahkan anak-anak saya biar tidak seperti saya yang buta huruf (Wawancara, 2019).

Menurut Ibu Mariani sebagai peserta PKH menyatakan bahwa PKH adalah bantuan buat orang yang kurang mampu yang mempunyai anak dibawah umur. Jadi disisni tidak semua orang miskin mendapatkan bantuan ini hanya keluarga yang mempunyai tanggungan saja. Seperti saya ini sangat bersyukur mendapatkan PKH ini karena bisa membantu untuk biaya anak saya yang masih sekolah di bangku SMP. Dulu sebelum saya dapat bantuan ini ya saya merasa sedih banget melihat anak saya sekolah, melihat sepatunya jebol, bajunya sangat-sangat tipis bahkan buku saja saya usahain utang dulu ditetangga saking penghasilan suami saya pas-pasan, ya gimana cuma buruh harian. Tapi Alhamdulillah setelah saya mendapatkan bantuan saya bisa membelikan sepatu, baju, tas dan buku, jadi saya bersyukur dengan bantuan ini bisa membantu perekonomian saya khususnya untuk anak saya yang sedang sekolah ini (Wawancara, 2019).

Hal serupa juga diutarakan oleh Ibu Lasmini yang mengatakan bahwa beliau membantu suaminya bekerja sebagai buruh harian untuk mendapatkan penghasilan tambahan karena ia menganggap biaya hidupnya masih kurang, pernyataan beliau sebagai berikut:

Menurut saya program ini untuk membatu orang miskin yang mempunyai anak sekolah, ibu hamil, lanjut usia dan disabilitas.Terus dengan adanya program ini sangat-sangat membantu saya selaku orang tidak mampu. Dalam program ini bisa membantu perekonomian saya khususnya untuk anak saya yang sedang sekolah dijenjang SMP dan SMA, karena jika saya mengandalkan penghasilan suami yang sebagai buruh tidak akan cukup untuk biaya anak sekolah di bangku SMP dan SMA, makanya saya cari tambahan, saya juga kerja di tempat tetangga. Maka dari itu saya sangat bersyukur mendapatkan bantuan ini (Wawancara, 2019).

Ada pula dari pendapat lain oleh ibu Hartati yang mengatakan bahwa saya merasa terbantu dengan adanya program ini, karena saat saya masih hamil sampai melahirkan ditanggung oleh PKH. Jadi bantuan ini bisa membantu perekonomian saya dan penghasilan suami bisa digunakan untuk keperluan sehari-hari (Wawancara, 2019).

Pelaksanaan kegiatan PKH sudah berjalan dengan baik, penerima bantuan telah melaksanakan persyaratan sesuai dengan yang telah ditetapkan Kementerian Sosial yang berkaitan dengan pendidikan dan kesehatan. Setelah ada program $\mathrm{PKH}$ pendidikan, anak 
lebih rajin bersekolah, dibidang kesehatan telah berjalan dengan baik. Bantuan dana diberikan setiap tiga bulan sekali (Anneke, Ngangi, \& Rengkung, 2017).

Dengan adanya PKH bisa membantu meringankan beban pendidikan dan kesehatan. Meskipun tidak seutuhnya menyelesaikan permasalahan-permasalahan yang ada di masyarakat, akan tetapi setidaknya dapat memberikan bantuan kepada masyarakat yang membutuhkan. Telah terlihat bahwasanya semangat orang tua untuk menyekolahkan anaknya agar bisa menjadi penerus bangsa dan agar kelak bisa hidup lebih sejahtera. Hal ini PKH telah berhasil menyelamatkan anak-anak yang kurang mampu untuk putus sekolah.

Kesehatan juga tidak kalah penting dengan pendidikan, kesehatan merupakan unsur yang harus dipenuhi dalam menjunjung nilai kemanusiaan (Sholichah, 2017). Pelayanan yang telah dirasakan oleh keluarga penerima manfaat di Desa Gereneng yang tanpa biaya, tidak mahal dan mudah dalam pelayanan salah satunya pelayanan kesehatan bagi ibu hamil, ibu nifas, lanjut usia dan disabilitas.

\section{Efektivitas Penyerapan Dana Bagi Kesejahteraan Masyarakat di Desa Gereneng Lombok Timur}

Berdasarkan teori yang ada bahwa PKH adalah program pemberian bantuan tunai bersyarat kepada Keluarga Penerima Manfaat (KPM) yang memenuhi syarat kepersertaan dan ditetapkan oleh kementrian sosial.Sebagai imbalannya Keluarga Penerima Bantuan (KPM) diwajibkan memenuhi persyaratan yang terkait dengan upaya peningkatan kualitas sumber daya manusia (SDM), yaitu pendidikan dan kesehatan (Kemensos, 2019). PKH adalah program pemberian bantuan sosial bersyarat kepada keluarga atau seseorang miskin dan rentan yang terdaftar dalam data terpadu program penanganan fakir miskin, diolah oleh pusat dasar dan informasi kesejahteraan sosial dan ditetapkan sebagai keluarga penerima manfaat PKH (Kemensos, 2018).

Berdasarkan hal tersebut, maka pemerintah membuat PKH yang bertujuan untuk mengupayakan masyarakat guna memenuhi kebutuhan dasar yang meliputi rehabilitas sosial, jaminan sosial, bemberdayaan sosial, dan perlindungan sosial dan pada realita yang terjadi dilapangan mengenai PKH haruslah sesuai apa yang telah ditentukan dan memiliki sasaran yang tepat dari PKH untuk penerima bantuan keluarga penerima manfaat. 
Beberapa pendapat masyarakat yang menguatkan mengenai ketersesuaian program pemerintah dengan yang ada dilapangan. Menurut pendapat ibu Surniwati bahwa susah kalau ditanya tentang hal seperti ini, karena tujuan pemerintah itukan sudah bagus untuk mencerdaskan dan mensehatkan masyarakat namun masih banyak penerima PKH yang menyalahgunakan uang mereka. Misalnya yang seharusnya untuk biaya sekolah digunakan untuk membeli baju dan kebutuhan yang lain. Saat diberi nasehat oleh pendamping mereka bilang ya namun nyatanya tetap seperti itu. Ya walaupun tidak semua seperti itu banyak juga yang menggunakan uangnya sesuai dengan anjuran pendamping dan ketentuan pemerintah dan mereka benar-benar menggunakan uang tersebut untuk biaya pendidikan anak, untuk cek kesehatan lainnya (Wawancara, 2019).

Kemudian pendapat yang lain dari bapak Sam menjelaskan bahwa harapan dari pemerinta itu kan membantu orang-orang yang kurang mampu untuk mengurangi beban hidup mereka. Permasalahan di lapangan yang saya perhatikan sebagai pendamping bisa menilai program ini masih kurang tepat sasaran. Kenapa? Karena diluar sana orang yang membutuhkan atau orang yang tidak mampu, tetapi mereka tidak mendapatkan bantuan tersebut. Sedangkan orang yang bisa dikatakan sudah mampu malah mendapatkan bantuan PKH ini. Oleh karena itu seharusnya program PKH ini perlu pendataan ulang, akan tetapi program ini sudah bagus dan berjalan dengan baik (Wawancara, 2019).

Ungkapan lain disampaikan oleh ibu Lina sebagai berikut:

Menurut saya sudah sesuai PKH ini, dulu di Desa Gereneng itu hanya lulusan SD dan SMP. Alhamdulillah dengan adanya program ini banyak yang bisa melanjutkan ke jenjang yang lebih tinggi atau ke jenjang SMA. Walaupun agak keberatan dalam kesehariannya atau dalam perekonomian, namun dengan adanya program ini bisa membantu perekonomian masyarakat yang kurang mampu. Jadi angka putus sekolah itu sudah berkurang, terus untuk kesehatan setelah adanya program keluarga harapan $(\mathrm{PKH})$ saya belum dengar anak yang lahir tidak normal atau cacat. Ibu-ibu hamil rutin memeriksakan kandungannya.Jadi menurut saya PKH di Desa Gereneng ini sudah bagus, telah tersalurkan dengan baik dan sesuai dengan tujuan pemerintah (Wawancara, 2019).

Begitu pula hasil wawancara dengan ibu Fatimah yang mengatakan bahwa sebenarnya sudah ada peningkatan tapi menurut saya belum maksimal karena masyarakat ini susah untuk diajak yang lebih baik, tetapi setidaknya dengan adanya program ini kehidupan masyarakat bisa hidup dengan lebih baik dari sebelumnya. PKH ini juga sudah membantu perekonomian masyarakat miskin dan membantunya untuk meringankan 
beban-beban atau tanggungan yang akan di dalam keluarganya tersebut (Wawancara, 2019).

Berdasarkan hasil wawancara di atas dapat disimpulkan bahwa PKH telah sesuai dengan apa yang direncanakan atau diperintahkan oleh pemerintah, karena masyarakat merasa terbantu dalam perekonomiannya dan masyarakat bisa lebih memahami pentingnya pendidikan dan kesehatan, sehingga masyarakat bisa lebih baik menjaga kesehatan dan pentingnya pendidikan. Namun sebagian masyarakat dalam hal ini belum memanfaatkan bantuan pemerintah ini dengan sebagaimana mestinya, sehingga tidak membuat masyarakat menjadi lebih baik. Dalam hal itu menjadikan masyarakat bersifat ketergantungan dari bantuan yang telah diberikan oleh pemerintah. Namun hal ini, meskipun ada masyarakat yang belum menjalankan program ini dengan baik pendamping tetap melakukan sosialisasi untuk menumbuhkan kesadaran masyarakat.

Berdasarkan di lapangan bahwa pelaksanaan PKH sudah mengarah kepada apa yang menjadi tujuan dari PKH yang telah dibuat, bersosialisasi pada masyarakat dan membantu masyarakat dalam menuntaskan masalah pendidikan serta berkurangnya angka disabilitas pada ibu melahirkan. Hal tersebut dikarenakan masyarakat menyadari akan kesehatan dan rutin memeriksakan kesehatannya.

Berikut beberapa wawancara pada masyarakat KPM, yakni Ibu Rodiyah. Ibu ini merupakan masyarakat asli Gereneng yang mempunyai anak berjumlah 4 orang, 1 orang diantaranya masih duduk dibangku sekolah. Salah satunya yang duduk dibangku SMA, sepulang sekolah anaknya ikut bekerja menjadi buruh harian. Namun setelah anaknya masuk dalam anggota PHK anaknya tidak lagi bekerja, tetap bersekolah seperti temanteman yang lain (Wawancara, 2019).

Selanjtnya ibu Suprin mengatakan bahwa alhamdulillah saya sudah menjadi peserta di PKH ini, setelah saya menjadi peserta sudah ada peningkatan. Saya jadi lebih tenang dalam menyekolahkan anak saya, karena biasanya pendapatan sehari-hari suami saya yang sebagai buruh itu hanya cukup untuk membiayai anak sekolah. Sekarang dengan adanya program ini masalah biaya sekolah sudah tercukupi dan sekarang jadi lebih bisa untuk kebutuhan lainnya (Wawancara, 2019).

Dengan kondisi tersebut dapat dikatakan bahwa PKH sangat berpengaruh terhadap pendidikan anak, karena pendidikan merupakan hal terpenting dalam membentuk karakter dan dapat memutuskan garis kemiskinan. Selain itu bidang kesehatan pun turut 
andil dalam kesejahteraan masyarakat. Hal ini seperti yang dikatakan oleh ibu Ratna Dewi bahwa dengan adanya program ini saya bisa memeriksakan kandungan saya sewaktu masih hamil. Setiap bulan saya rutin ke Posyandu untuk memeriksakan kandungan saya. Tujuannya supaya nanti pada waktu melahirkan semua berjalan normal dan lancar. Alhamdulillah sampai saya melahirkan semua berjalan lancar dan bayi saya sehat. Jadi saya bersyukur dan berterimakasih sudah mendapatkan bantuan ini karena bisa membantu kesehatan anak-anak saya terutama yang masih balita ini. Program ini sangat membantu perekonomian keluarga saya (Wawancara, 2019).

Dengan adanya bantuan PKH bisa membantu dalam mensejahterakan masyarakat yang menerima bantuan baik berupa dana atau pengetahuan lainnya. Bantuan yang diberikan pendamping PKH untuk bisa menghasilkan dan keterampilan sehingga menjadi modal untuk membuka lapangan kerja. Semakin meningkatnya kesadaran orang tua untuk mendorong anak-anak mereka untuk melanjutkan pendidikan hingga SMA/sederajat. Dimana syarat utama dari program PKH ini ialah memiliki anak usia sekolah, ibu hamil, lanjut usia dan disabilitas. Yang mana diharapkan dana tersebut dapat digunakan dalam memenuhi kebutuhan pendidikan dan kesehatan (Diana, 2018).

Berdasarakan penjelasan di atas, peneliti mengamati bahwa pendidikan dan kesehatan merupakan aspek sangat penting bagi kehidupan yang harus terpenuhi secara optimal sehingga masyarakat dapat menjalankan fungsi sosialnya. PKH yang ada di Desa Gereneng mengalami peningkatan, terbukti dengan kondisi sosial KPM yang saat ini mengalami perubahan yang lebih baik. Dalam hal ini diharapkan masyarakat Desa Gereneng agar selalu berinteraksi dengan baik dengan pendamping PKH karena peran pendamping sangat dibutuhkan untuk membimbing dan membina, meningkatkan hubungan masyarakat guna tercapainya keberlanjutan PKH bagi masyarakat penerima bantuan, sehingga masyarakat bisa hidup lebih mandiri dan tidak bergantung pada program pemerintah.

\section{Kesimpulan}

PKH adalah program pemberian bantuan tunai bersyarat kepada Keluarga Penerima Manfaat (KPM) yang memenuhi syarat kepersertaan dan ditetapkan oleh Kementrian Sosial. Sebagai imbalannya Keluarga Penerima Bantuan (KPM) diwajibkan memenuhi persyaratan yang terkait dengan upaya peningkatan kualitas sumber daya 
manusia (SDM), yaitu pendidikan dan kesehatan. Pelaksanaan kegiatan PKH di Desa Gereneng sudah berjalan dengan baik. Partisipasi para KPM sangat tinggi baik dalam pendidikan dan kesehatan. Dalam konteks ini penerima PKH dapat merasakan bahwa dalam aspeks pendidikan terlihat keaktifan siswa di sekolah semakin meningkat, dan angka putus sekolah semakin berkurang. Kemudian dalam hal kesehatan, masyarakat yang kurang mampu menjadi lebih peduli dengan kesehatannya, terutama untuk ibu hamil dan anak balita. Ibu-ibu penerima PKH yang memiliki anak balita secara rutin memeriksakan anak mereka ke Posyandu supaya kesehatannya tetap terjaga dengan baik.

\section{Daftar Rujukan}

Anneke, R. M., Ngangi, C. R., \& Rengkung, L. R. (2017). Efektivitas Ketepatan Sasaran Dalam Penyaluran PKH Keluarga Petani Kelurahan Meras Kecamatan Bunaken Kota Manado. AGRI-SOSIOEKONOMI, 13(3), 45-56.

Arikanto Suharsimi. (2013). Metode Penelitian Kualitatif, Jakarta: Rineka Cipta.

BPS NTB, (2018). Data tentang Kemiskinan 2011-2016 di Lombok Timur.

BPS NTB, (2018). Data tentang Pengangguran Bulan Agustus di Lombok Timur.

Diana, R. (2018). Analisis Efektivitas Program Keluarga Harapan (PKH) Terhadap Pengurangan Kemiskinan Dalam Perspektif Ekonomi Islam (Studi Pada Desa Kota Jawa Kecamatan Way Khilau), Skripsi, Lampung: UIN Raden Intan Lampung.

Ekardo, A., Firdaus, F., \& Elfemi, N. (2014). Efektifitas Program Keluarga Harapan (PKH) Dalam upaya Pengentasan Kemiskinan di Nagari Lagan Hilir, Kab. Pesisir Selatan. Jurnal Ilmu Sosial Mamangan, 3(1), 1-9.

Fauziyah, R. N. (2018). Faktor-faktor yang Mempengaruhi Tingkat Pengangguran Terbuka di Pulau Jawa Tahun 2010-2015. Skripsi. Yogyakarta: UII.

Fidyatun, E. (2012). Evaluasi Program Keluarga Harapan (Pkh) Bidang Kesehatan di Kabupaten Brebes Tahun 2011. Jurnal Kesehatan Masyarakat Universitas Diponegoro, 1(2).

Hardoyo, Eko. (2015). Masyarakat Indonesia, Yogyakarta: Ombak

Husni, Ihlal Jamilatul. (2018). Program Keluarga Harapan (Pkh) Dan Dampaknya Terhadap Kehidupan Sosial Ekonomi Masyarakat Desa Leming Kecamatan Terara Kabupaten Lombok Timur. Skripsi. Lombok Timur: Universitas Hamzanwadi.

Kemensos, (2019). Program Keluarga Harapan (PKH), https://kemensos.go.id/programkeluarga-harapan-pkh. Dikses 2019.

Ma'arif, A. I. (2018). Pengaruh Bantuan Sosial Program Keluarga Harapan (PKH) Terhadap Kesejahteraan Keluarga Miskin di Kecamatan Grogol Kota Cilegon Banten, Skripsi. Serang: Universitas Islam Negeri Banten.

Peraturan Menteri Sosial Republik Indonesia Nomor 1 Tahun 2018 tentan Program Keluarga Harapan. 
Profil Desa Gereneng Tahun 2018.

Sholichah, N. (2017). Apresiasi Masyarakat Miskin Terhadap Layanan Sosial Dasar Pemerintah, Jurnal Komunikasi Profesional, 1(1), 1-21.

Sugiyono. (2017). Metode Penelitian Kuantitatif, Kualitatif dan R\&D. Bandung: Alfabeta.

Tayo Anom, (2018). Pengaruh Pendapatan Terhadap Kesejahteraan Masyarakat Desa Sembalun Kabupaten Lombok Timur (Studi Kasus Pada Usaha Tani Kentang Tahun 2017), Skripsi, Lombok Timur: Universitas Hamzanwadi.

Weru, S. (2019). Analisis Persepsi Masyarakat Tentang Program Keluarga Harapan (PKH), Kualitas Pendampingan, dan Pengelolaan Dana Bantuan di Desa Ngreco, Weru, Sukoharjo. Skripsi. Yogyakarta: Universitas Sanata Dharma.

Wibowo, S. (2012). Kajian Implementasi Program Keluarga Harapan Sebagai Salah Satu Program Peningkatan Derajat Kesejahteraan Masyarakat Miskin di Kabupaten Ngawi, Skripsi, Surakarta: Universitas Sebelas Maret. 